\title{
EXPLORATORY STUDY OF THE MAIN LEAN TOOLS IN CONSTRUCTION PROJECTS IN PERU
}

\author{
Andrews A. Erazo-Rondinel ${ }^{1}$ and Cristian Huaman-Orosco ${ }^{2}$
}

\begin{abstract}
Lean Construction (LC) has been applied in various construction projects in Peru for over 20 years in different projects: buildings, roads, sanitary works, mining, sports infrastructure, energy, oil, and industrial plants; as well as a series of tools such as Last Planner® System (LPS), takt time, visual management, among others. However, in Peru, practitioners are focused on LPS, leaving aside other lean tools that can help manage construction projects. The research aims to identify the main lean tools applied in Peru's construction projects and classify them according to the project type. First, a literature review of lean tools applied in Peru is conducted; second, expert judgments are interviewed to validate the tools, and fourteen main LC implementation tools are identified. Then, one hundred and twenty-four engineers answered the survey from various types of projects and classified the primary tools that have been implemented in their respective projects. The data is analysed by linear correlation and reliability. It was found that the primary tools used in Peru are: LPS, Visual Management (VM), Continuous Improvement, Feedback, Big Room, and Value Stream Mapping (VSM). The study found that professionals do not know the benefits of each tool or when to apply it. Also, the professionals implement few tools in the design stage of the projects.
\end{abstract}

\section{KEYWORDS}

Lean construction, tools, benefits, Perú, Latin America.

\section{INTRODUCTION}

Implementing lean tools has had key benefits in the construction industry for better cost and time control, greater safety, and other benefits (Arbulú and Zabelle, 2006). Thus, in Peru, they have been implemented since 1997 (Ghio 1997), achieving the following benefits: generating and adding value for the client (Orihuela et al. 2019; Erazo et al. 2020), increasing productivity, and reducing waste (Yoza 2011; Román and Juárez 2014), delivering the project to the client on time (Flores and Orello 2013; Murguia et al. 2016), and improving communication, and collaboration (Gómez et al. 2018). Ghio (2001) identifies the factors that generate low productivity in Peruvian construction and proposes three lean tools: LPS, work sampling method, and takt time. LPS is the tool most used by professionals in Peru (Murguia 2019). The benefits of LPS are to generate a more

Teaching Assistant, Faculty of Civil Engineering, Universidad Nacional de Ingeniería, Lima, Peru, aerazor@uni.pe, orcid.org/0000-0002-5639-573X

2 Graduate Student, Faculty of Civil Engineering, Universidad Nacional de Ingeniería, Lima, Peru, chuamano@uni.pe, orcid.org/0000-0002-8125-3768 
predictable workflow and speed in scheduling, design, and construction of projects (Ballard et al., 2007). These benefits served to motivate professionals to put in place Lean in various projects in Peru. Likewise, the need to complement them and improve their potential led them to put them on par with other tools such as balance charts, feedback, and visual management (Gómez et al., 2018).

Tools such as Value Stream Mapping (VSM), Target Value Delivery (TVD), and Integrated Project Delivery (IPD) have been inserted as pilot plans as part of testing and learning (Medina 2014). VSM has had a better application in linear projects to standardize processes in different work fronts and map processes (Róman and Juárez 2014). TVD has been incorporated only as a pilot plan and occasionally (Gutiérrez 2020). IPD has taken relevance since 2018 to involve project stakeholders and reach the project scope with defined timelines (Erazo et al. 2020; Gómez et al. 2018). Also, the increased adoption of Building Information Modeling (BIM) has motivated professionals to use Big Room, LPS, Virtual Design Construction (VDC), tack time, and Choosing By Advantages (CBA). BIM-enabled pre-conceptualization of the project, allowing for better decision making, more accurate and collaborative planning, safer work fronts, and strategies for a continuous workflow (Gómez et al. 2018; Gutiérrez 2020; Suarez et al. 2020).

In addition, Peruvian public projects present different problems. In 2018, the number of public projects paralyzed was 867 (Auditor-General of Peru, 2019. The main reasons for these were technical deficiencies and contractual non-compliance (39\%), exceeding the cost $(28 \%)$ and time of that formulated in their technical file (15\%). These problems mentioned above are frequently in Peru's projects. LC is a good solution to the previous problem, but it is necessary to show the Lean tools that are used and their respective benefits. Through this study, the professionals will know recent results (most used tools and their benefits) of Lean implementation (the last study was in 2001).

\section{LITERATURE REVIEW}

For this stage, a literature review of IGLC articles from 1997 to 2020 is carried out. The articles are filtered by the word Peru, and the publications were also reviewed year by year. As a result, 26 articles evaluating Peruvian construction projects are identified. These are classified according to the tools applied and the benefits of each type of project. Table $\mathrm{N}^{\circ} 1$ shows this analysis according to the type of tool and its respective implementation project. 
Table 1. Use of lean tools by project type in Peru.

\begin{tabular}{|c|c|c|}
\hline Lean tool & Source & Projects Implemented \\
\hline LPS & $\begin{array}{l}\text { (Arbulu y Soto 2006; Brioso 2011; Flores y Ollero } \\
\text { 2013; Ghio 1997; Murguia 2019; Murguía et al. } \\
\text { 2016; Orihuela et al. 2019; Román y Juárez 2014; } \\
\text { Suarez et al. 2020; Yoza 2011) }\end{array}$ & $\begin{array}{l}\text { Buildings, Highway } \\
\text { Infrastructure, Energy and } \\
\text { Oil, Mining, Sanitary and } \\
\text { sewerage infrastructure }\end{array}$ \\
\hline VSM & (Murguía et al. 2016; Román y Juárez 2014) & $\begin{array}{c}\text { Highway Infrastructure, } \\
\text { Buildings }\end{array}$ \\
\hline IPD & (Gomez et al. 2018; Medina 2014) & $\begin{array}{l}\text { Highway Infrastructure, } \\
\text { Buildings }\end{array}$ \\
\hline Lean in design & $\begin{array}{l}\text { (Arbulu y Soto 2006; Brioso 2011; Orihuela } \\
\text { et al. 2019) }\end{array}$ & $\begin{array}{c}\text { Highway Infrastructure, } \\
\text { Buildings }\end{array}$ \\
\hline Big Room & (Gomez et al. 2018; Gutiérrez 2020) & $\begin{array}{l}\text { Highway Infrastructure } \\
\text { and Buildings }\end{array}$ \\
\hline $\begin{array}{c}\text { Visual } \\
\text { Management }\end{array}$ & (Guzman y Ulloa 2020; Orihuela et al. 2019) & $\begin{array}{l}\text { Buildings and sports } \\
\text { infrastructure }\end{array}$ \\
\hline LBMS & $\begin{array}{l}\text { (Murguía et al. 2016; Murguia y Urbina 2018; } \\
\text { Suarez et al. 2020; Yoza 2011) }\end{array}$ & $\begin{array}{l}\text { Buildings, Sanitary and } \\
\text { sewerage infrastructure }\end{array}$ \\
\hline Takt Time & (Murguia y Urbina 2018) & Mining and Buildings \\
\hline $\begin{array}{l}\text { Continuous } \\
\text { Improvement }\end{array}$ & (Murguia et al. 2020) & Buildings \\
\hline Feedback & (Izquierdo et al. 2011) & Buildings \\
\hline $\begin{array}{l}\text { Continuous } \\
\text { Flow }\end{array}$ & (Villagarcia 2011) & $\begin{array}{l}\text { Buildings and Highway } \\
\text { Infrastructure }\end{array}$ \\
\hline $\begin{array}{l}\text { Information } \\
\text { management }\end{array}$ & (Gutiérrez 2020; Villagarcia 2011) & $\begin{array}{l}\text { Buildings and Highway } \\
\text { Infrastructure }\end{array}$ \\
\hline LPDS & (Brioso 2011; Medina 2014) & Buildings \\
\hline Standardization & (Flores y Ollero 2013) & $\begin{array}{l}\text { Sanitary and sewerage } \\
\text { infrastructure }\end{array}$ \\
\hline Target Cost & (Gutiérrez 2020; Medina 2014) & Buildings \\
\hline CBA & (Gomez et al. 2018; Suarez et al. 2020) & $\begin{array}{l}\text { Buildings and Highway } \\
\text { Infrastructure }\end{array}$ \\
\hline A3 Report & (Gomez et al. 2018) & $\begin{array}{l}\text { Buildings and Highway } \\
\text { Infrastructure }\end{array}$ \\
\hline
\end{tabular}

\section{RESEARCH METHOD}

To better understand the study phenomenon, the authors followed the method used in Figure $\mathrm{N}^{\circ} 1$. The study had a mixed approach, as it considered a qualitative and quantitative approach to take a better "snapshot" of the study phenomenon at a given time (Cresswell, 2014). Quantitative questions were asked through closed-ended questions to tools and benefits. The qualitative questions served to corroborate the data and give space to relate experiences of particularities of the interviewees (these accounts revealed particular benefits of LC). 


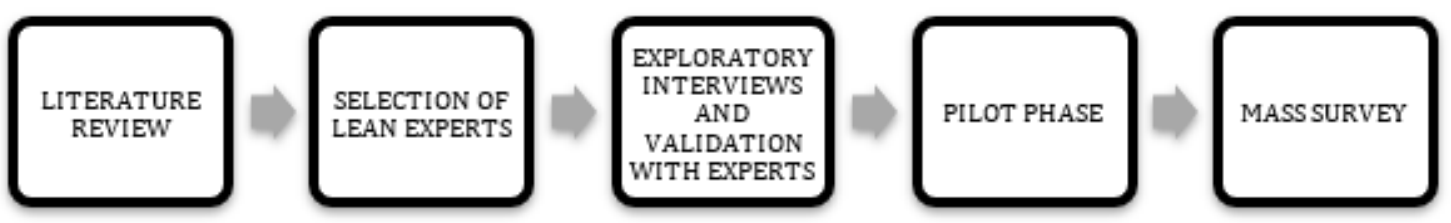

Figure $\mathrm{N}^{\circ} 1$. Diagram of the method Proposed.

\section{SELECTION OF LEAN EXPERTS}

Table $\mathrm{N}^{\circ} 2$ shows the profile of the six selected experts. Nine experts were selected, but only six met the requirements according to the objectives of the study: Civil Engineer with more than 10 years of experience implementing lean in the sector of study and professionals with teaching experience, published articles and at least a master's degree.

Table 2. Characteristics of lean experts

\begin{tabular}{|c|c|c|}
\hline Expert & Experience & Description \\
\hline Building & 15 years & $\begin{array}{l}\text { Civil Engineer, consultant, and Lean Implementer in mega- } \\
\text { projects of real estate, educational centers, hospitals, and } \\
\text { shopping centers. Advanced Instructor of the Peruvian } \\
\text { chapter of Lean Construction. }\end{array}$ \\
\hline Infrastructure & 12 years & $\begin{array}{l}\text { Civil Engineer, consultant, and Lean implementer in highway } \\
\text { and railroad infrastructure megaprojects. }\end{array}$ \\
\hline Mining & 13 years & $\begin{array}{l}\text { Civil Engineer, consultant, and Lean implementer in the } \\
\text { largest Peruvian mining companies. }\end{array}$ \\
\hline $\begin{array}{l}\text { Industrial } \\
\text { Plants }\end{array}$ & 10 years & $\begin{array}{l}\text { Industrial Engineer and Lean implementer, production and } \\
\text { planning engineer in major industrial plants in Peru. } \\
\text { Advanced Instructor of the Peruvian chapter of Lean } \\
\text { Construction. }\end{array}$ \\
\hline $\begin{array}{l}\text { Energy and } \\
\text { Oil }\end{array}$ & 13 years & $\begin{array}{l}\text { Civil Engineer, manager of energy, oil, and gas projects. } \\
\text { Advanced Instructor of the Peruvian chapter of Lean } \\
\text { Construction. }\end{array}$ \\
\hline $\begin{array}{l}\text { Sports } \\
\text { infrastructure } \\
\text { and roads }\end{array}$ & 12 years & $\begin{array}{c}\text { Civil engineer and lean implementer in sports megaprojects. } \\
\text { Senior lecturer at Peruvian universities. }\end{array}$ \\
\hline
\end{tabular}

\section{EXPLORATORY INTERVIEWS AND VALIDATION WITH EXPERTS}

The interviews with the experts are semi-structured: This starts with selecting experts according to the type of project. The next step is knowing the professional profile of the expert and his experience in the various projects where they have taken part and implemented LC. Later, the research team collected the tools they used in their project and the benefits they got. Finally, the expert reviews the survey and give the feedback according to their expertise. All interviews are archived and stored; based on the feedback from the experts in the interviews, the research team adjusted the surveys.

\section{Questionnaire Design and Data Collection}

The survey was structured as follows: (1) General data; (02) Professional data: this section collects information on company size, years of experience of the participants, (03) Lean tools: knowledge and application of the tools in their projects. (04) Lean Benefits: The professionals' perceptions got by using the Lean tools in their projects are evaluated. (05) Final aspects: Information and data care is collected from the participants in this section. 
The final questionnaire is answered by one hundred and twenty-four professionals and is conducted virtually. The tools were evaluated with the Likert scale from 1 to 5 points, asking the respondents to evaluate the tools they most frequently used in their project as "Never=1, Rarely=2, Occasionally=3, Frequently=4 and Very frequently=5". The benefits they got after using the Lean tools were evaluated with the Likert scale from 1 to 5 points, asking the respondents to evaluate which were the benefits they perceived the most in their project as "Strongly disagree=1, Somewhat disagree=2, Neither agree nor disagree $=3$, Somewhat agree $=4$ and Strongly agree $=5 "$.

\section{RESULTS AND DISCUSSION}

The questionnaire was validated by experts and the consistency of the results by Cronbach's Alpha $(\alpha)$ with a consistency of 0.92 or an $8 \%$ error. Table 3 shows the relevant results of the 124 respondents.

Table 3. Bibliographic characteristics of the survey respondents.

\begin{tabular}{ccc}
\hline Demographic Characteristics & Frequency & Percentage \\
\hline Experience & & \\
$1-5$ years & 82 & $66.39 \%$ \\
$6-10$ years & 24 & $19.33 \%$ \\
$11-15$ years & 10 & $7.56 \%$ \\
$16-20$ years & 6 & $5.04 \%$ \\
More than 20 years & 2 & $1.68 \%$ \\
Experience working with lean. & & \\
$1-2$ years & 51 & $41.13 \%$ \\
$3-5$ years & 38 & $30.65 \%$ \\
$6-8$ years & 21 & $16.94 \%$ \\
$9-10$ years & 12 & $9.68 \%$ \\
More than 10 years & 2 & $1.61 \%$ \\
Size of organization & & \\
micro (1 to 10 people) & 27 & $22 \%$ \\
small (10 to 50 people) & 32 & $26 \%$ \\
medium (50 to 250 people) & 30 & $24 \%$ \\
Large (more than 250 people) & 35 & $28 \%$ \\
\hline
\end{tabular}

The figures below show the most used tools according to the type of project. The code " $\{\mathrm{n}=\mathrm{x}\}$ " represents the tool " $\mathrm{n}$ " used by "X" professionals. Where the value of " $\mathrm{x}$ " is the number of professionals who use the tools only "frequently" and "very frequently."

Table 4 shows the ranking of the tools most used by professionals in Peru and their comparison with other countries. The percentages are calculated based on the total number of respondents. The results show remarkable growth in applying LTs in Peru compared to other countries around the world and other Latin American countries. Most of the LTs used are related to their diffusion, popularity, and benefits. However, the A3 report shows a growth of more than $20 \%$ compared to other countries. Its use would be related to the ease of transmitting ideas quickly and effectively. They are avoiding extensive reporting and accumulation of non-relevant information in project control. SBD has a remarkable increase in creating many designs for the client based on recent technologies, such as sustainable buildings, smart buildings, new technological materials, 
or creating customized departments for each client. But none of the most used LT are related to design or integration between all stages of the project. The lack of knowledge of the other tools could be the cause of the problems in Peruvian construction.

Table 4. Comparison of lean tools

\begin{tabular}{ccccc}
\hline Description & Peru (2021) & $\begin{array}{c}\text { Chile(Salvatierra } \\
\text { et al. 2015) }\end{array}$ & $\begin{array}{c}\text { Colombia(Castiblanco } \\
\text { et al. 2019) }\end{array}$ & $\begin{array}{c}\text { Global(McGraw } \\
\text { Hill 2013) }\end{array}$ \\
\hline $\begin{array}{c}\text { Number of } \\
\text { respondents }\end{array}$ & 124 & 25 & 254 & 193 \\
LPS & $62.9 \%\{n=78\}$ & $100 \%\{n=25\}$ & $18.11 \%\{n=46\}$ & $30 \%\{n=58\}$ \\
VM & $50 \%\{n=62\}$ & $45 \%\{n=11\}$ & $10.24 \%\{n=26\}$ & --- \\
Continuous & $41.9 \%\{n=52\}$ & $55 \%\{n=14\}$ & --- & --- \\
Improvement & & & & --- \\
Kanban & $33.9 \%\{n=42\}$ & $1 \%\{n=1\}$ & $4.72 \%\{n=12\}$ & $20 \%\{n=39\}$ \\
Big Room & $31.5 \%\{n=39\}$ & --- & & --- \\
A3 Report & $25.8 \%\{n=32\}$ & $9 \%\{n=3\}$ & $3.15 \%\{n=8\}$ & --- \\
Gemba & $25.8 \%\{n=32\}$ & $100 \%\{n=25\}$ & $1.97 \%\{n=5\}$ & $21 \%\{n=41\}$ \\
VSM & $19.4 \%\{n=24\}$ & $18 \%\{n=5\}$ & $6.69 \%\{n=17\}$ & $15 \%\{n=29\}$ \\
CBA & $18.5 \%\{n=23\}$ & --- & $5.12 \%\{n=13\}$ & $24 \%\{n=47\}$ \\
TVD & $12.9 \%\{n=16\}$ & --- & $6.3 \%\{n=16\}$ & --- \\
\hline SBD & $9.7 \%\{n=12\}$ & --- & $1.97 \%\{n=5\}$ & \\
\hline
\end{tabular}

Figure 2 shows the ten most used tools in building projects (shopping centers, hospitals, real estate, educational centers, and others), in infrastructure projects (roads, sanitation works, trains, and other linear works), and energy, gas, oil, and industrial plant projects. In building projects, LPS and VM are the most frequently used tools to improve collaboration and planning between specialties. Big Room allows project stakeholders to make decisions, work collaboratively and engage through LPS. The integration of these three LTs allows engineers to perform segmentation, continuous flow, and design understanding. Compared to similar studies in Peru, building projects have matured to a greater degree LC. Professionals integrate design and construction. However, client value mapping is still minimal. Also, decision-making and cost control are still not perceived in building projects. In infrastructure projects most of the tools are focused on the construction stage. Projects of this type of longitudinal need a great effort to control different work fronts. A3 reporting is an excellent alternative to a large amount of information reported on many work fronts. This allows interpreting the information quickly and efficiently. It can be identified that the tools are more focused on the division of labor, such as LPS and process tracking (Kanban). Continuous Improvement and Work Sampling are focused on waste identification. These tools are due to the extensive earthworks and the focus on machinery to optimize and save time. 


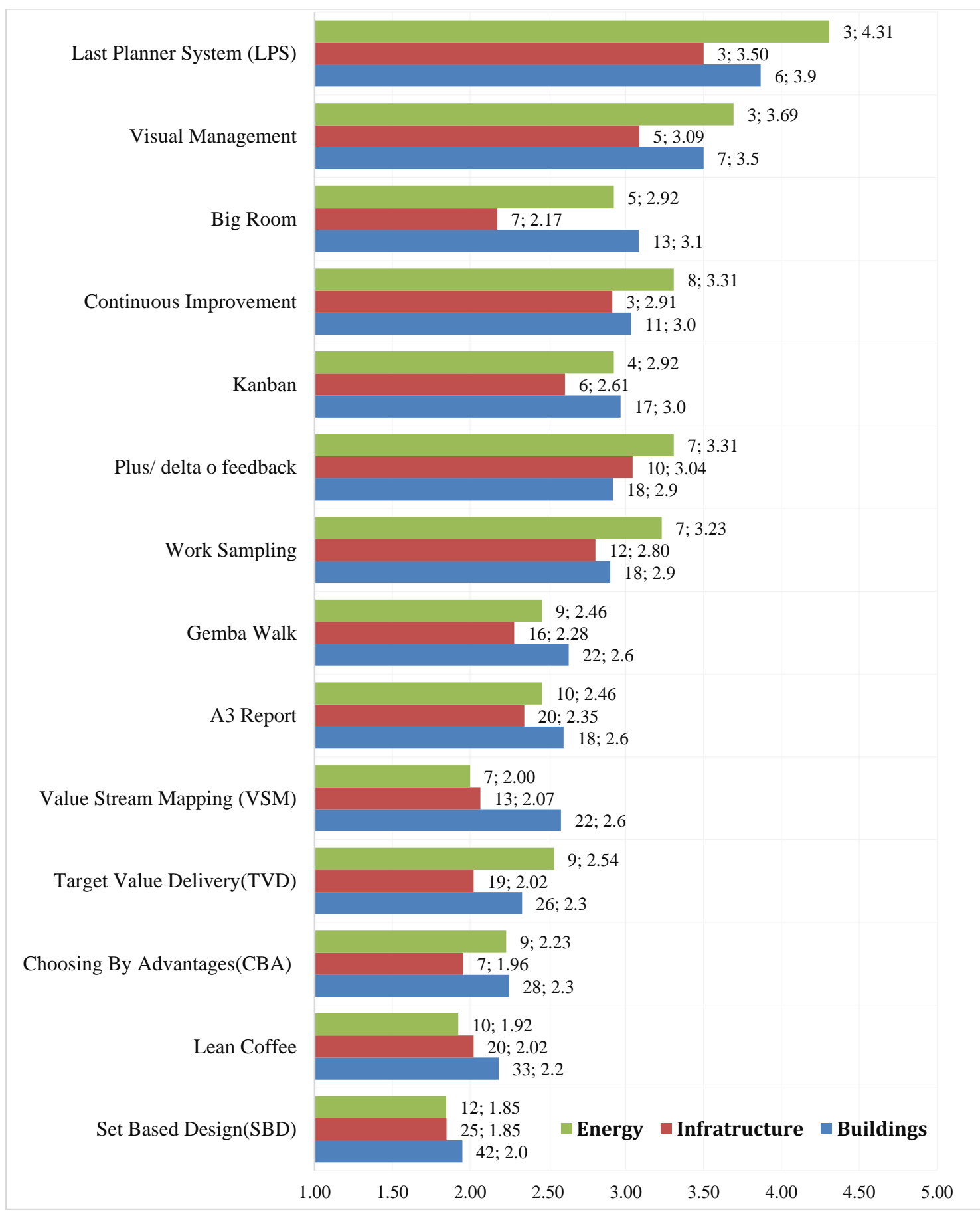

Figure 2. Most used tools in construction projects in Peru

Finally, Figure 3 shows the ten main tools used in the project design and formulation stage. Professionals in this field are unaware of any other tools besides the known ones. TVD and SBD have a notable use by professionals to generate better designs to the client's scope. The tools allow the integration of the clients and the designer. However, they still do not develop tools that allow the integration of stakeholders in the construction stage. This could be the main factor that causes deficiencies in the technical file and contractual problems. There are still very few practitioners of these tools frequently (three to five practitioners). 


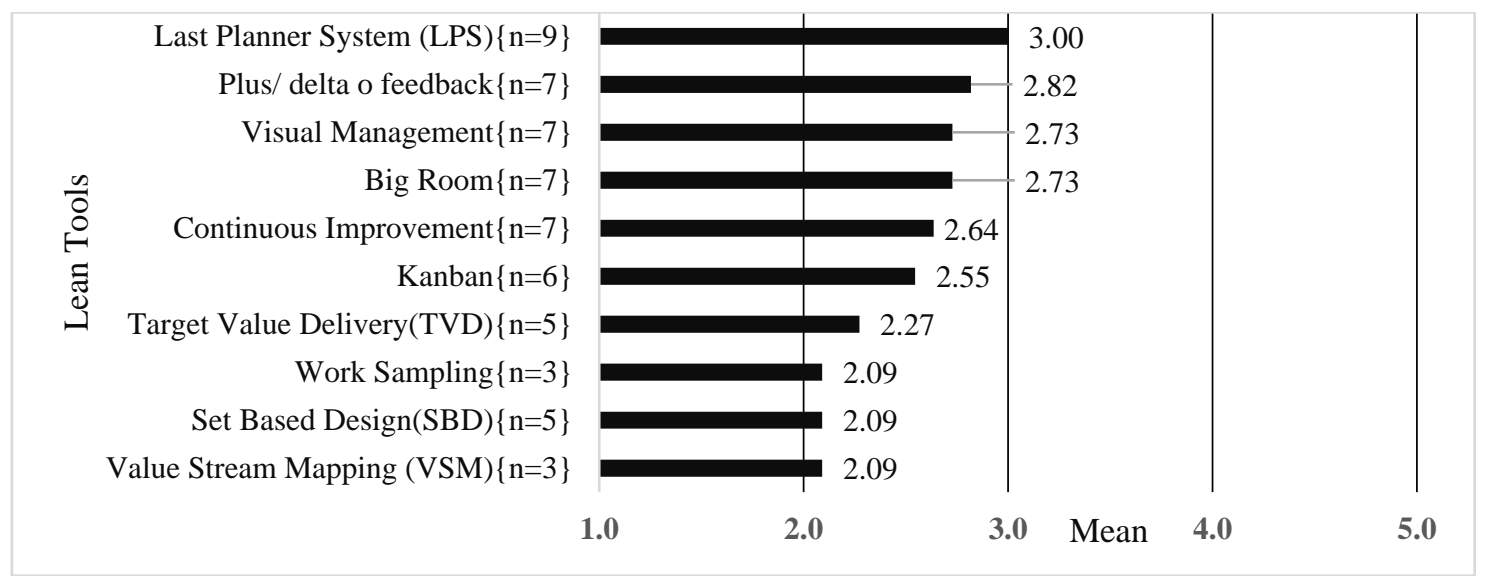

Figure 3. Lean tools most used in the design and formulation of projects.

Figure 4 shows the benefits obtained by lean practitioners. The benefits are correlated to the most used tools. The benefits of lean compared to McGraw Hill Construction (2013) do not differ much. For example, according to the study, the improvement of planning is $79 \%$ compared to $80 \%$ of the mentioned literature. So, we can say that the benefits of lean tools in Peru are quite correlated to the global literature.

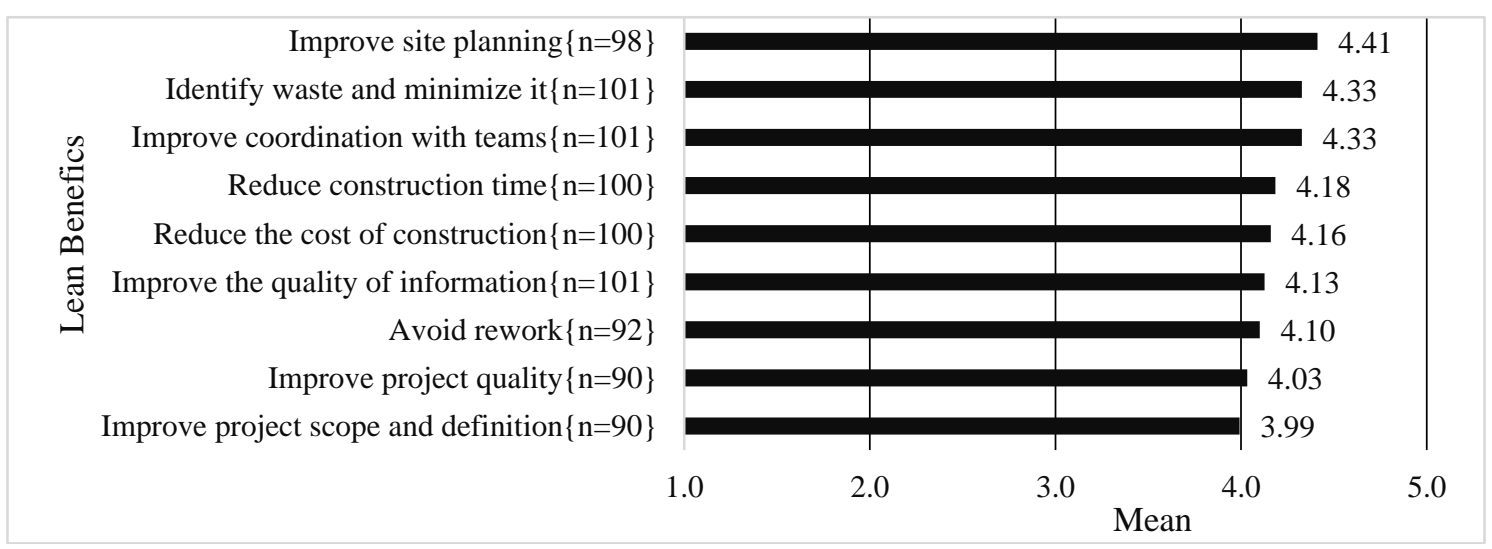

Figure 4. Lean benefits

Looking at the results of the application of the LTs in each type of project, it is evident that there is no correlation of data between the construction and design stages. So, it is necessary to carry out studies to show why professionals do not use lean in the design stages. Generating designs without observing the entire project is also a way to generate problems and waste in the construction stage (Huthwaite 2012). LT has been applied to a greater extent in building and infrastructure projects. The results of its application are notorious in the benefit charts. However, it is necessary to identify the benefits of each tool in energy, oil, and industrial plant projects, to encourage professionals to become Lean practitioners.

\section{CONCLUSIONS}

The exploratory results show that the most used tool in Peru is LPS in projects of buildings, road infrastructure, sanitation, trains, energy, oil, and industrial plants. The analysis shows that professionals and companies are more focused on the construction stage, leaving aside the design and integration stages of the project stakeholders. Even the construction industry in Peru is still working in silos, focusing objectively only on the 
project stage they oversee. Also, there is little motivation in professionals to use design tools such as TVD and Big Room. Big Room has been the tool that is taking more relevance at this stage, generating good design strategies, and making it even more powerful with BIM use. Finally, there is still a long process to include IPD in Peruvian companies to integrate all stages and stakeholders of the project. However, using Lean tools in the diversity of projects generates a promising long-term Lean maturity in the companies. The benefits obtained so far in the study show a correlation close to the global literature references. It is expected that the results shown will motivate Peruvian professionals to become Lean practitioners. The authors recommend developing a study about the drivers and barriers that motivated the use of LC in the design process. Also, it is essential to develop exploratory studies of SBD, TVD, and other tools to know the maturity of these tools in Peruvian projects.

\section{REFERENCES}

Arbulu, R., y Soto, J. (2006). "A Design Case Study: Integrated Product and Process Management". Proc. 14th Annual Conference of the International Group for Lean Construction, Santiago, Chile.

Arbulu, R. \& Zabelle, T. 2006, 'Implementing Lean in Construction: How to Succeed' Proc. 14th Annual Conference of the International Group for Lean Construction. Santiago, Chile.

Ballard, G., Howell, G., Tommelein, I., y Zabelle, T. (2007). "The Last Planner Production System Workbook". Lean Construction Institute, San Francisco, California, USA, 81pp, 82.

Brioso, X. (2011). "Applying lean construction to loss control". Proc. 19th Annual Conference of the International Group for Lean Construction, Lima, Peru.

Castiblanco, F. M., Castiblanco, I. A., y Cruz, J. P. (2019). "Qualitative Analysis of Lean Tools in the Construction Sector in Colombia". Proc. 27th Annual Conference of the International Group for Lean Construction, Dublin, Ireland.

Cresswell, J.W., (2014). Research Design. Qualitative, Quantitative and Mixed methods approach 4th ed., London: Sage.

Erazo, A., Guzman, G., y Espinoza, S. (2020). "Applying BIM Tools in IPD Project in Perú". Proc. 28th Annual Conference of the International Group for Lean Construction, Berkeley, California.

Flores, G., y Ollero, C. (2013). "Productivity Improvement Applying Production Management in Projects with Repetitive Activities". Proc. 21 st Annual Conference of the International Group for Lean Construction, Fortaleza, Brazil.

Ghio, V. A. (1997). "Development of Construction Work Methods and Detailed Production Planing for on-Site Productivity Improvement”. Proc. 5th Annual Conference of the International Group for Lean Construction, Gold Coast, Australia.

Ghio, V. (2001). Construction Site Productivity. Pontificia Universidad Católica del Perú, Lima.

Gomez, S., Ballard, G., Naderpajouh, N., y Ruiz, S. (2018). “Integrated Project Delivery for Infraestructure Projects in Perú". Proc. 26th Annual Conference of the International Group for Lean Construction, Chennai, India.

Gutiérrez, F. M. (2020). "Influence of Integrated Teams and Co-Location to Achieve the Target Cost in Building Projects". Proc. 28th Annual Conference of the International Group for Lean Construction, Berkeley, California. 
Guzman, G., y Ulloa, W. (2020). "Bim Application in the Operation and Maintenance Management of a Sports Infrastructure". Proc. 28th Annual Conference of the International Group for Lean Construction, California, USA, 949-960.

Huthwaite, B. (2012). The Lean Design Solution. A practical guide to streamlining product design and development. Mackinac Island, Michigan: Institute for Lean Innovation.

Izquierdo, J. L., Cerf, M., y Gómez, S. A. (2011). "Lean Construction Education: Basic Management Functions Workshop". Proc. 19th Annual Conference of the International Group for Lean Construction, Lima, Peru.

Medina, A. (2014). "Learning Through Failure: The Challenge of Lean Project Delivery from the Contractor's Perspective in Perú". 22nd Annual Conference of the International Group for Lean Construction, IGLC 2014, Oslo, Norway.

McGraw Hill Construction Research y Analytics. (2013). Lean Construction Leveraging Collaboration and Advanced Practices to Increase Project Efficiency. SmartMarketReport, (M. Hill, ed.), Bedford.

Murguia, D. (2019). "Factors Influencing the Use of Last Planner System Methods: An Empirical Study in Peru". Proc. 27th Annual Conference of the International Group for Lean Construction, Dublin, Ireland.

Murguía, D., Brioso, X., y Pimentel, A. (2016). “Applying Lean Techniques to Improve Performance in the Finishing Phase of a Residential Building". Proc. 24th Annual Conference of the International Group for Lean Construction, Massachusetts, USA.

Murguia, D., Felix, K. M., y Guerra, M. A. (2020). "An Approach to Capture Design and Construction Lessons Learned From Facility Managers". Proc. 28th Annual Conference of the International Group for Lean Construction, California, USA.

Murguia, D., y Urbina, A. (2018). "Complex Production Systems: Non-Linear and NonRepetitive Projects". Proc. 26th Annual Conference of the International Group for Lean Construction, Chennai, India.

Orihuela, P., Noel, M., Pacheco, S., Orihuela, J., Yaya, C., y Aguilar, R. (2019). "Application of virtual and augmented reality techniques during design and construction process of building projects". Proc. 27th Annual Conference of the International Group for Lean Construction, Dublin, Ireland.

Román, B., y Juárez, G. (2014). “A Lean-Triz Approach for Improving the Perfomance of Construction Projects". Proc. 22nd Annual Conference of the International Group for Lean Construction, Oslo, Norway.

Salvatierra, J. L., López, A., Alarcon, L. F., y Velásquez, X. (2015). “Lean Diagnosis for Chilean Construction Industry: Towards More Sustainable Lean Practices and Tools". Proc. 23rd Annual Conference of the Internatioanl Group for Lean Construction, Perth, Australia.

Suarez, J. C., Zapata, J., y Brioso, X. (2020). "Using 5D Models and CBA for Planning the Foundations and Concrete Structure Stages of a Complex Office Building". Proc. 28th Annual Conference of the International Group for Lean Construction, California, USA.

The Auditor General of the Republic of Peru (2019). Stalled Works Report 2019. Lima, Peru.

Villagarcia, S. (2011). "Formalization as a Way of Coordination and Control in a Construction Firm". Proc. 19th Annual Conference of the International Group for Lean Construction 2011, IGLC 2011, Lima, Peru.

Yoza, A. (2011). "Impact of 'The last planner' Method on Sanitation works". Proc. 19th Annual Conference of the International Group for Lean Construction, Lima, Peru. 